\title{
FIVE UNPUBLISHED COINS OF ALEXANDER THE GREAT AND HIS SUCCESSORS IN THE RHODES UNIVERSITY COLLECTION ${ }^{1}$
}

\author{
J D Snowball \& W D Snowball (Rhodes University)
}

\begin{abstract}
The article briefly discusses the economic and political significance of the Alexander III ("the Great") type silver tetradrachm and publishes three of his coins currently held by the Rhodes University Classics Museum. Based on stylistic elements, they are classified as from the Amphipolis and Arados mints and were probably minted during his lifetime. Two further tetradrachms from the empires of Alexander's successors, Ptolemy II and Seleucus IV, are also published.
\end{abstract}

\section{Introduction}

Despite Alexander the Great's relatively short reign, and whatever one may think of his methods, his influence on the ancient world was undoubtedly enormous. One indication of this is the extent to which his tetradrachm coinage type was used as a medium of exchange long after his death in countries many thousands of kilometers from Macedon.

Mints manufacturing the extremely popular silver tetradrachm of the Alexander-type were spread all over territories controlled by the Hellenistic kings from Amphipolis in Macedon, estimated to have minted about 11.2 million coins during his reign (Le Rider 2003:84), to Syria, the central areas of Asia Minor and as far east as Bactria (Mackay 1971:59). Coins of this type were also minted in Africa (Carthage, Numidia, Mauritania), Britain and the nearby Germanic regions (Regling 1969:34) For example, Orodes II of Parthia (57-38 BC) still struck Hellenistic coin types with legends in Greek and, on the reverse, an image of the king seated and facing left, recalling the Zeus figure on the Alexander type coins (Sear 2002, vol. 2:700, catalogue number 7433). As with the coins of his father, the minting of the Alexander type continued for some time after his death.

The widespread use of the Alexander type coins and, in some places, their continued posthumous use, is interesting from an economic point of view because, while the metal content of the coins remained important, it appears that the guarantee offered by what was stamped on the coins also had some value (Bellinger 1963:1-2). Money (today, as in previous times) has three functions: it acts as a medium of exchange, a store of value and a unit of account (Parkin et al. 2005:582). Fiat money does not have to have any intrinsic value, but it must be guaranteed by the state that issues it and be generally accepted in order to perform its functions. One could argue that the currency unification that resulted from Alexander's vast empire and the subsequent importance of his currency type, was the beginning of fiat money. Certainly, as will be discussed further below, the idea of placing the ruler's portrait on the coinage, so common today, appears to have emerged for the first time in the Heracles/Alexander type.

The authors would like to thank Professors John Atkinson and David Wardle of the University of Cape Town for their very useful comments on the paper, and Mr Oliver King of the Rhodes University physics department for his assistance in calculating the specific gravity of the coins. 
The advantage of minting coinage on the same standard as that of one's major trading partners was well known at the time. Philip II, Alexander's father, used the Thracian weight for some of his first tetradrachms in order to facilitate trade with the Chalcidians, and the Attic weight for his very popular gold Philippeioi, minted from the gold of the Thracian mines at Crenides, of which he gained control in 357BC (Seltman 1955:199-201; Carradice 1995:57)2. Alexander's coinage, however, was designed to link together a much larger empire and it is now generally accepted that he took over the Persian weight system (Bellinger 1963:2) ${ }^{3}$. Thanks also to what Seltman (1955:205) calls the "uncanny foresight" of Alexander's selection of his particular types, his coins helped to weld his heterogeneous empire together. They were so successful, in fact, that Alexander's generals, who took over parts of his empire after his death, continued for some time to mint Alexander-type coins. This was partly because they were widely accepted, but also partly as propaganda, for, as Hardy (1974) suggests, the support of the deified Alexander was seen to be an important way for the successors to verify their own kingships ${ }^{4}$.

Tetradrachms were not intended for use at the level of market trade, but were mostly used for paying soldiers and for state transactions, like large-scale international trade, gifts, tax payments and even as a commodity marketed by those states which had mines of precious metal and mints to those with no precious metals. A tetradrachm was worth four drachms and 24 obols and Bellinger (1963:30) calculates that a tetradrachm would support a person (at the level of "bare subsistence") for 12 days. Goldsborough (2005:2) estimates that it represented about four days pay for a common labourer ${ }^{5}$. The ratio between gold and silver was also important and, as Bellinger (1963:31) suggests, probably based on the ratio between the bullion values of the metals. However, changes in demand and, particularly, supply of the metals could change the gold to silver ratio. For example, Philip's mining activities at Pangaeus increased the gold supply and dropped the ratio from about 11 or 12:1 to about 10:1, which means that one gold stater equalled 5 tetradrachms. Similarly, Alexander's capture of various Persian treasuries would have significantly increased the supply of both metals, although Bellinger (1963:31) reports that the ratio remained at 10:1 for a fairly long time.

The aim of this article is to provide a general context for the collection of the silver tetradrachms of Alexander and of his successors, held by the Rhodes University Classics Museum. Specific coins will then be discussed further.

2 There is some evidence that Alexander continued to mint the coins of Philip for some time after he became king and only started minting his own coin types much later on, although the date that he started minting his new type is much debated (see Bellinger 1963:9-11; Goldsborough 2005; British Museum Compass collections online, 2005, Le Rider 2003:164-5, Kontes, online).

3 Carradice (1995:59) notes that, while Alexander's coin types were certainly dominant, he did allow the minting of certain "local" coins for example in Cilicia, Babylonia and Mesopotamia.

4 Cartledge (2004:55) also comments on the way in which rulers and would-be rulers adopted the "symbolic attributes" of Alexander in order to "bolster their own claims".

5 In South Africa, the current minimum wage is R4.10 per hour or R32.80 for an 8 hour day. Four day's wages would amount to about R131 (a "bare subsistence" for 12 days at just over R10 per day). 


\section{The Alexander type}

Most of the silver tetradrachms of Alexander (except for a few special commemorative issues) follow a specific and very easily recognizable pattern. Basically, the obverse shows a profile head of Heracles wearing the lion skin helmet, while the reverse shows Zeus seated on a throne, leaning on a sceptre and holding out his hand on which his sacred eagle has alighted. The legend in the field reads $\mathrm{A} \Lambda \mathrm{E} \Xi \mathrm{AN} \triangle \mathrm{POY}$ (of Alexander), sometimes with $\mathrm{BA} \Sigma \mathrm{I} \Lambda \mathrm{E} \Omega \Sigma$ (king) which was added only after he became the recognized king of the Persian Empire (Seltman 1933:212).

The choice of Heracles for the obverse of the coin is not surprising, since both Alexander and Philip regarded him as their ancestor and patron and a number of previous Macedonian kings (Archelaus, Amyntas III and Perdiccas III) had also used this coin type (Sear 2002, vol. 1. catalogue numbers 1497, 1508 and 1514). After Philip captured Amphipolis in 357BC, he minted a series of gold staters showing Heracles in the lion skin headdress (Sear 2002, vol. 1, catalogue numbers 1448-1452), a design which Alexander continued. There is a great deal of debate about whether the features of Heracles are meant to show Alexander's profile ${ }^{6}$. Some scholars (Mackay 1971:60; Quennell \& Hodge 1979:71; Seltman 1955:213) argue that Alexander did not use his own profile on any of the coins minted during his lifetime, except for certain special commemorative coins or medallions, like the series of bronze portrait coins minted in Egypt in 332BC (Carradice 1995:59) The best example of these shows the battle against King Poros at the Jhelum River in India, although even here, there is some debate about whether the Macedonian horseman shown attacking the retreating elephant is, in fact, Alexander (Holt 2003) ${ }^{7}$. Others (Bellinger 1963:14-19 and Goldsborough 2005), suggest that Heracles may have come to show Alexander's features more and more during his lifetime, either on the initiative of individual artists or as a deliberate policy, emphasizing his divinity.

After Alexander's death, certain of the generals may have substituted the profile of Alexander for that of Heracles - the first example of this thought to have been produced by Lysimachus of Thrace, who minted a silver tetradrachm showing a profile of the deified Alexander with the ram's horns of Zeus/Ammon on his temples (Mackay 1971:61). Even after this, subsequent Greek rulers seem to have been hesitant about blatantly minting coins showing their own profiles (with the notable exception of the Ptolemies), preferring, as Mackay (1971:62) points out, to partly conceal them by using mythical figures such as Pan, "whose features were suspiciously like those of Antigonus".

The reverse of the coins shows the seated Zeus, whom, in the form of Ammon, Alexander regarded as his special patron deity and, perhaps, his divine father (Arr. Anab. 3.3). The iconography is very old, first appearing on a coin dated to around 460BC - a silver hemidrachm obol of the Arcadian League - which showed on the obverse Zeus Lykaios in a pose very similar to that of the Alexander-type, but facing either left or right, with a simpler throne and the eagle on Zeus' right arm, rather than the left (LIMC, volume 8 1981-1997:362). Others argue that the

$6 \quad$ While most authors agree that, until Alexander's death in 323BC portraits of living people did not appear on coins at all, Seltman (1955:199) and Bellinger (1963:18) refer to a suggestion that the first tetradrachms which Alexander's father, Philip, minted on his accession to the Macedonian throne, showed the king's name printed over a bearded horseman who "almost certainly represents the king [Philip] himself" (Seltman 1955:199).

7 Excellent reproductions to be found in Davis \& Kraay 1973. 
figure is based on the chryselephantine statue by Pheidias of Zeus at Olympia (although there are considerable differences as outlined by Bellinger 1963:22) or even that he is meant to represent Baal from the obverse of coins from Tarsus, which supposes that Alexander only started minting his own coinage very late in his reign (Goldsborough 2005:5). M.J. Price (cited in Le Rider 2003:164) concludes that the mint masters in Tarsus were switched to producing coins for Alexander with the same basic design (seated Zeus/Baal) as they had been producing for Mazaius, in which case the iconography would have been Persian originally. Much rests on the debate about when Alexander began to produce his own coins (as opposed to continuing with his father's type), as mentioned previously.

An interesting feature of the Zeus figure is the way it changes after, and even during, Alexander's lifetime to resemble more and more the Zeus at Olympia by Pheidias (Bellinger 1963:22). By carefully grouping the Alexander type coins catalogued by M J Price, Goldsborough (2005:7-22) develops various tests to determine the probability that any particular Alexander coin is a lifetime issue or not. One of the most significant tests is whether the legs of the Zeus figure are crossed or uncrossed, crossed legs (as in the Pheidias statue) being associated with a much higher probability that the coin is not a life time issue.

The artistic value of Hellenistic coins dating from this period is questioned by numismatists who lament the variety and vigour of earlier coins in which the gods were portrayed with realism and feeling. Seltman (1949:23) in particular feels keenly that the emergence of "god-men", beginning with Alexander, eroded artists' faith in the gods so that they "grew more and more into the semblance of puppets". Regling (1969:42) agrees that the glyptography of coins "no longer went hand in hand with the great art of the [Hellenistic] period". This is certainly observable in the rendering of the figure of Zeus on the Alexander-type tetradrachms, on which the god often appears stiff and unrealistic, without even clearly defined features, perhaps because the number of mints and the volume of emissions overstretched the supply of skilled workers.

However, as Regling (1969:42) notes, much of the ingenuity that previously went into representing the gods, was now directed towards compelling portraits of the "god-men", often easily recognizable and sometimes quite revealing. Such portraits continued to be used by Alexander's successors and eventually became an accepted institution, even to present times, when coins have come to be associated with the portraits of rulers (Quennell \& Hodge 1979:71).

Like Philip, Alexander soon realized that the adoption of a common standard for his coinage would be a very astute economic move. Alexander abandoned Philip's dual system (Thracian for silver, Attic for gold) and adopted the Attic standard for his gold, silver and bronze coins as well. While this could be interpreted as a compliment to Athens, it also made economic sense, since Athens owned the only silver mines in Greece and, after the foundation of the Corinthian League in 338, it was expedient for Macedon to have a monetary system to match the one dominant in Greece in order for money to perform its important function as a medium of exchange ${ }^{8}$.

As Price (1974:23) mentions, however, Alexander faced a dilemma in this area, since Philip's tetradrachms were of a weight used only by Macedonia and Thrace, but were also accepted by inland tribes with which Macedon traded a good deal. In order to phase in the Attic weight, Alexander appears to have gone on minting tetradrachms in the name of Philip, specifically for trade in this area. 
The change to the Attic standard was also important in terms of money's function as a unit of account: Arrian $(7,9: 6)$ reports that Alexander inherited debt of 500 talents and borrowed 800 more to cross to Asia. Running this sort of government deficit would certainly have been easier if indebtedness could be signalled using a common currency.

So pervasive did the Alexander-type become that lesser local systems eventually faded out (Seltman 1933:205). Apart from the notable exception of the Ptolemies in Egypt, the Attic standard continued to be maintained by Alexander's successors after his death (Regling 1969:40).

As Kraay (1976:8) points out, the value of coins struck from precious metals was determined primarily by the amount of metal they contained, and accuracy in minting is thus quite high. $\mathrm{He}$ argues that 'apparent anomalies may be due as much to wear, corrosion or damage as to original carelessness'. Except for a very few examples, however, no ancient coins from this period have an indication of their value as part of the inscription (Regling 1969:44). The median weight for tetradrachms on the Attic standard was 17.2g (Kraay 1976:329), and, as will be seen, most of the coins examined are fairly close to this weight despite centuries of wear and damage.

In addition to the choice of a common standard to facilitate commerce, the Alexander-types also appealed to a wide range of people in an artistic and symbolic sense, which Seltman (1955:205) attributes to Alexander's amazing luck:

"Though introduced in 336BC these types were destined to appeal equally to Greek and to Oriental subjects of Alexander as yet unconquered; for the Phoenician was to see in the obverse type his own god Melqart, the Cilician was to regard the seated deity as the great Ba'al of Tarsus and the Babylonian, though he might not be able to read the Greek name of Alexander, was to look on pictures that might recall his own Gilgamesh, the lion-slayer, and the figure of Bel-Marduk, god of Babylon. When it is realized that, next to Macedonia, the greatest mints of Alexander were to be established precisely in Phoenicia, Cilicia, and Babylon, the uncanny foresight that the king showed in the selection of these types becomes apparent".

The basic pattern for the coin, as detailed above, was produced in a vast number of styles and places over a very long period of time and any one coin confronts the collector with two major difficulties: firstly, the dating of it - most importantly, to determine whether the coin is a lifetime issue, and secondly, the determining of the geographical location or mint of the coin (Head 1887:199).

There are a number of Alexander-type coins in the Rhodes University Classics Museum, which have, to the best of our knowledge, never been published before. It is believed that the Alexander coins were bought, along with the rest of the museum's quite extensive Greek and Roman coin collections, by Prof. K D White from a variety of reputable antiquities dealers in Europe. They are, however, not well catalogued. The following section of this article will examine three of the most interesting and well-preserved examples of Alexander type coins and make some suggestions about their date and provenance. 
Coins from the Amphipolis Mint

Of the twenty official mints for Alexandrian coins, Amphipolis was one of the most important and productive and was the headquarters for Alexander's European coinage?

The attribution of specific coins to particular mints was first thought to be a relatively simple matter of determining the meaning of the symbols and letters on the reverse of coins, usually found under Zeus's throne or in the field in front of Zeus. These symbols were considered to be mint-marks each denoting a separate mint. Except for fairly obvious attributions (to be discussed later) it is now accepted that coins can only be reliably attributed to specific mints by die-linked sequence marks or by stylistic similarities (Kraay 1969:15). The latter method will be employed for the recognition of the Rhodes coins.

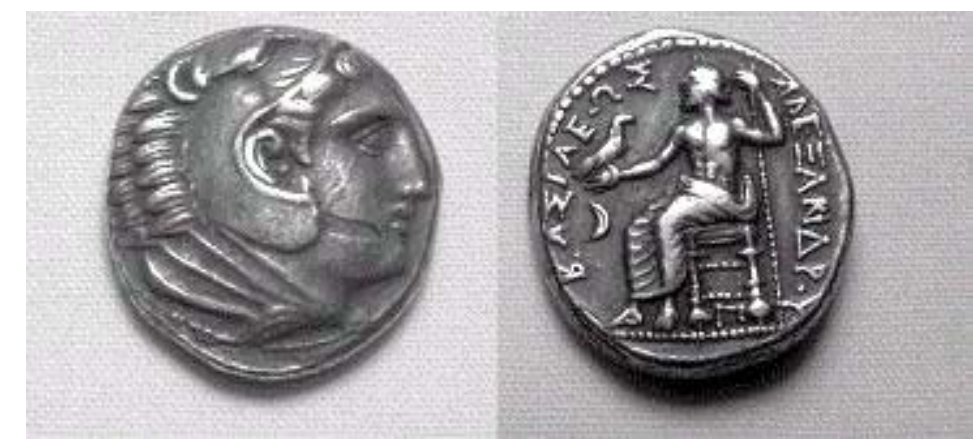

Fig. 1.1

Obverse: Profile head of young Heracles, r.;

Reverse: Zeus seated on backless throne, 1, his legs parallel, holding eagle and sceptre; on 1., $\mathrm{BA} \Sigma \mathrm{I} \Lambda \mathrm{E} \Omega \Sigma$; on r., A $\Lambda \mathrm{E} \Xi \mathrm{AN} \Delta \mathrm{POY}$; in field to left, sickle moon.

Weight: $17.2 \mathrm{~g}$; specific gravity $10.7 \mathrm{~g} / \mathrm{cm}-3(+/-2.7 \mathrm{~g} / \mathrm{cm}-3)$.

Diameter: 22mm; Axis: Obv. 厄 Rev. 』

The first coin (Fig. 1.1) shows a particularly fine profile head of Heracles on the obverse with, on the reverse, Zeus enthroned and the legend A $\triangle E \Xi A N \triangle P O Y$ behind the throne and $\mathrm{BA} \Sigma \mathrm{I} \Lambda \mathrm{E} \Omega \Sigma$ in front of it. Since the addition of 'king' is thought to have been done only after Alexander became king of Persia, this may help with the dating. In fact, the three largest Alexandrian mints (Amphipolis, Babylon and Tarsus) were all slow to add BA $\Sigma \mathrm{I} \Lambda \mathrm{E} \Omega \Sigma$ to their coins - it appears on Amphipolis coins only from about 325BC (Seltman 1933:212). In the field in front of the throne is a sickle moon symbol and the letter $\Pi$ under the throne. These marks are now thought to refer to specific coin issues or even to be associated with particular governors or mint operators and so, for the most part, are of no use in classifying the coins (Kraay 1976:5).

The profile head is beautifully executed and highly suggestive of a portrait of Alexander, rather than Heracles. The curl of the lion-skin helmet around the ear is reminiscent of the horn of

9 "During eighteen years, over 700 obverse-dies and about 1300 reverse-dies were employed for silver tetradrachms in that one mint [Amphipolis] alone" (Seltman 1933:207). 
Zeus/Ammon - an attribute frequently used on coins when indicating the deified Alexander. However, on closer examination, this is found not to be so, for a tiny lion's fang can be seen protruding from the end of the jaw.

The obverse side of this coin, however, shows some damage, a relatively deep gouge having been made in the cheek. Kraay (1976:16) suggests that such marks could be test cuts, made to determine whether the coin was solid silver (as opposed to silver-plated copper, of which many ancient examples survive) ${ }^{10}$. This seems rather unlikely in the case of an Alexander-type coin, which was accepted as currency in many parts of the world outside of Greece and continued to circulate for a long time. However, the cut is fairly carefully made (unlike other examples) and seems designed not to obscure the legend or deface the coin too badly, but goes just deep enough to reveal any plating. Given the wide use of such coins, it is not surprising to find this evidence that some of them must have been faked. The specific gravity of the coin shown in figure 1.1 is also shown to be close to that of pure silver ${ }^{11}$ (King 2005).

Goldsborough (2005:9-10) outlines five tests to apply to any Alexander-type coin to determine the probability that it is a lifetime edition, based on M J Price's cataloguing of the Alexander-type coins. Firstly, as previously mentioned, coins showing Zeus's legs uncrossed are more likely (a 55\% chance) to be lifetime editions. Secondly, only posthumous issue coins from a very small number of the mints (about 10\%) show decorative elements on the back of Zeus's throne. Thirdly, the absence of the royal title BA $\Sigma \mathrm{I} \Lambda \mathrm{E} \Omega \Sigma$ increases the probability of the coin being a lifetime issue. The final two tests have to do with coin size and weight: coins weighing 17.2 grams or more are more likely to be lifetime issues, as are coins with smaller flan sizes (24 to $25 \mathrm{~mm}$ or less).

Applying these tests to the coin in figures 1.1, the uncrossed legs of Zeus, lack of any decorative elements on his throne back, weight (exactly 17.2g) and small flan size (22mm from side to side) suggest that it is a lifetime edition. While the royal title decreases this probability somewhat, "king" was added to some coins minted later on in Alexander's reign and it is thus suggested that this coin is dated to $325-323 \mathrm{BC}^{12}$.

10 "Finds show that such tests were normally performed outside the Greek world, when the coins had ceased to be treated as the currency of individual states and had become so much bullion to be sub-divided as required" (Kraay 1976:16).

11 The specific gravity of silver is $10.5 \mathrm{~g} / \mathrm{cm}-3$.

12 An interesting comparison is an electrotype (a copy of an ancient coin using an electroplating process) of an Alexander coin, also in the Rhodes collection, from the Rhodos mint, dated to the second century BC. This coin shows Zeus with crossed legs and the royal title and a much larger flan size, all of which, according to Goldsborough (2005:16) indicate that the coin is a posthumous issue. 


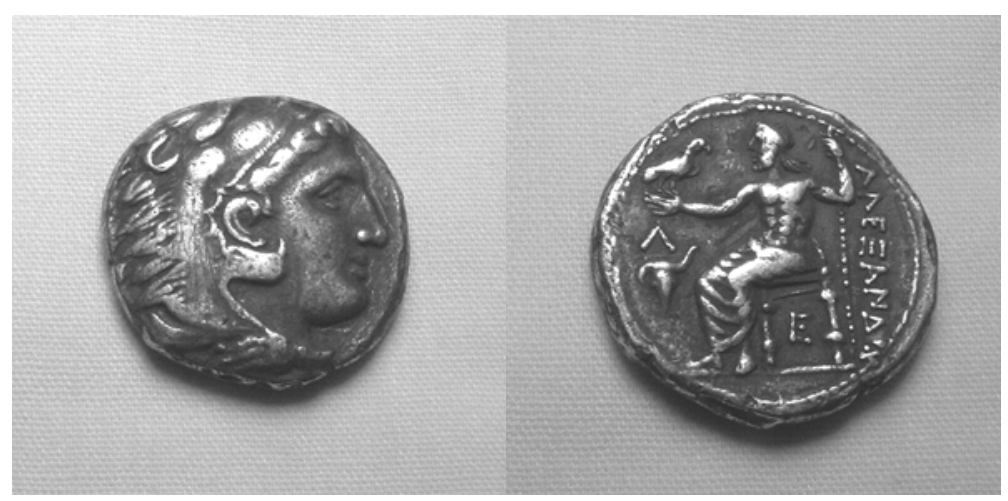

Fig. 1.2

Obverse: Profile head of young Heracles, r.;

Reverse: Zeus seated on backless throne, 1 , his legs parallel, holding eagle and sceptre; on r., $\mathrm{A} \Lambda \mathrm{E} \Xi \mathrm{AN} \triangle \mathrm{POY}$; in field to left, $\Lambda$ and a bucranium.

Weight: $16.29 \mathrm{~g}$; specific gravity $9.0 \mathrm{~g} / \mathrm{cm}-3(+/-2.0 \mathrm{~g} / \mathrm{cm}-3)$

Diameter: $24 \mathrm{~mm}$

Axis: Obv. $\circlearrowright \quad$ Rev. $\lesssim$

The second coin from the Amphipolis mint (Fig. 1.2) is less finely fashioned than the first, and more worn. The profile head of Heracles is very similar to the first coin. The reverse shows Zeus and the legend $\mathrm{A} \Lambda \mathrm{E} \Xi \mathrm{AN} \triangle \mathrm{POY}$ with a $\Lambda$ and a bucranium (stylized ox head) in front of the throne and an E below. While the letters could mean any number of things, Kraay (1976:3) remarks that the provenance of a coin can be suggested by symbols indicating things that brought wealth or fame to a particular district. He refers specifically to cattle as being one of the major sources of wealth for the Macedonians before the Hellenistic era, and which were used frequently by them on a coin type. Perhaps the bucranium on the Alexander-type coin, also found on other coins from the Amphipolis mint, recalls the source of wealth in days gone by and helps to establish the provenance of the coin as Macedonia.

Applying the five Goldsborough (2005:15) tests, the uncrossed legs of Zeus and the absence of the royal title indicate a $69 \%$ chance of the coin being a lifetime edition. The absence of throne decorations and the fairly small flan size $(24 \mathrm{~mm}$ from side to side) are also positive indications, but the atypically light weight (16.29g) suggests a posthumous issue. However, the specific gravity is once again acceptably close to pure silver, so one might argue that the fairly extensive wear on the coin is at least partly to blame for its lighter than average weight. Goldsborough (2005:10) does also comment that "a fair percentage of lifetime coins weigh slightly less than 17 grams". We thus suggest that it is an early lifetime edition dated somewhere after Alexander's accession in 336, but before the royal title was added in 325BC.

The reasons for attributing these two coins to the Amphipolis mint are otherwise largely stylistic. The mane of the lion skin helmet on the obverse is shown in a particularly spiky way, not seen on coins from other mints, and the way that the lion skin is drawn up under the chin in 
folds and knotted is also characteristic. The features of Heracles/Alexander have a particularly Greek look, with a straight nose, high cheekbones, a curved mouth and a distant gaze. The Zeus on the reverse of the coins is shown seated with the right leg forward and the left back, the left foot in three quarter view and his robe draped in soft folds over the back leg. The musculature of his chest is well defined and all the fingers of his outstretched hand are shown in a particularly stiff and stylized way.

Coin from the Arados mint

The mint at Arados was one of the four big Phoenician mints, which began to produce Alexander-type tetradrachms and gold staters in about 332BC. According to Seltman (1955:210), this mint began to add some letters of its name (AP or A) to the obverse of its coins (under Zeus's throne) and is one of the few cases in which such mint marks may be useful. The coin held by the Rhodes University Classics museum shows an A under the throne. (Fig 1.3).

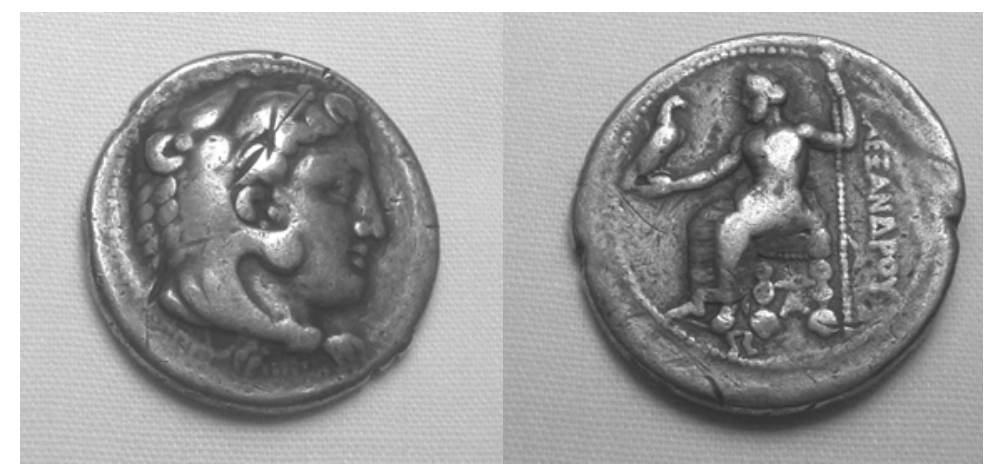

Fig. 1.3

Obverse: Profile head of young Heracles, r. ; reverse: Zeus seated on backless throne, 1, his legs parallel, holding eagle and sceptre; on r., A $\Lambda \mathrm{E} \Xi \mathrm{AN} \triangle \mathrm{POY}$; in field below throne, $\mathrm{A}$

Weight: $16.65 \mathrm{~g}$; specific gravity $9.8 \mathrm{~g} / \mathrm{cm}-3(+/-2.3 \mathrm{~g} / \mathrm{cm}-3)$

Diameter: $26 \mathrm{~mm}$

Axis: Obv. $\circlearrowright \quad$ Rev.

In addition to the mint mark, the Rhodes coin shows other stylistic similarities to coins from the Arados mint (Wildwinds.com). On the obverse, the lion skin helmet is shown with less precision than in coins from some other mints, although the fang along the jaw bone is still visible, and the two lion's paws are shown knotted beneath the chin. The lion's mane is far less pronounced than on coins from, for example, the Amphipolis mint and, while the Heracles profile is very similar to those on the two previous coins discussed, the features are not as fine and the jaw is more prominent. 
On the reverse, Zeus is shown sitting on a throne with a crosspiece very high up, almost under the seat, indicated by raised dots on each leg. The legs of the throne are shown using three raised dots and the material of his robe is depicted in regular, parallel pleats, arranged in twos, on his right leg. There is also the suggestion of a footstool. All these features are common on Alexander-type coins from the Arados mint (Wildwinds.com) ${ }^{13}$. Around the rim of the coin are several 'test cuts' serving the same purpose as the gouge found on the first Amphipolis mint coin - that of determining whether the coin was solid silver (Kraay 1976: 16), which, from the specific gravity test, it appears to be.

The five Goldsborough (2005) tests produce very similar results to the coin shown in figure 1.2. In favour of the coin being a lifetime edition are the uncrossed legs of Zeus, the lack of throne decorations, the absence of the royal title and a flan size fairly close to the average $(26 \mathrm{~mm})$. Against it is the slightly lighter than average weight (16.65 grams), perhaps partly as a result of the test cuts, but in this case, a very similar coin from this mint is dated to $328-320 \mathrm{BC}$ (Wildwinds.com), which makes it probable that the Rhodes coin is a lifetime edition.

\section{Coinage of the Dynasties of Alexander's Generals}

In addition to the examples of Alexander-type coinage, the Rhodes Classics museum also holds two coins minted by two of the three royal houses of Alexander's successors. Once his empire had been carved up and the initial wars of succession were over, three major houses emerged. They were, the Antigonids of Macedonia, the Seleucids of Syria and the Ptolemies of Egypt.

\section{Ptolemies of Egypt}

Ptolemy I initially ruled Egypt as a governor in the name of Philip and then Alexander IV, minting coins using the Alexander-type with Alexander's portrait replacing that of Heracles. Although Alexander IV is thought to have died in $310 \mathrm{BC}$, his death was only admitted in $306 \mathrm{BC}$. Ptolemy I took the royal title a year later, and then began placing his own portrait on his coins (Sear 2002, vol. 2:731). As Milne (1931:111) points out, Ptolemy inherited a largely native Egyptian population who traditionally regarded the Pharaoh/King as divine. The use of his portrait on these coins is thus unlikely to have caused much comment. Even so, he generally appears with the aegis of Zeus - a divine attribute (Reglin 1969:37). The successors of Ptolemy I generally used, not their own portraits, but that of the founder of the dynasty - a practice which continued until the end of their line. Exceptions were only made for commemorative occasions and in the case of Cleopatra IV, who used her own portrait (Milne 1931:111).

13 Wildwinds.com is a very useful website to consult for the identification of a wide variety of ancient coins although, as Goldsborough (2005) notes, it is far from complete. The site is a record of coins that have been sold at auction, complete with photographs, a brief description and the price for which they were sold. 


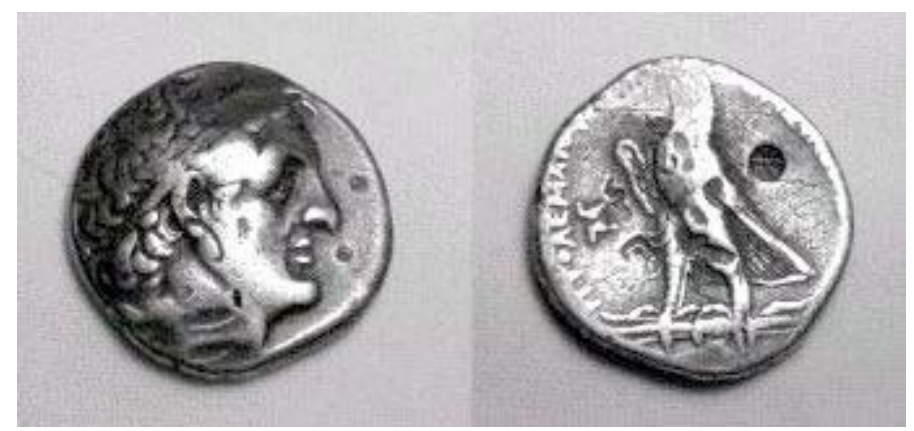

Fig. 2.1

Obverse: Profile head with diadem of Ptolemy I, r. wearing aegis;

Reverse: Standing eagle, 1, holding thunderbolt; in field on 1., a monogram (illegible) and $\Pi T O \Lambda E M A I O Y / B A \Sigma I \Lambda E \Omega \Sigma$; in field on r., punch mark

Weight: 14.02 ; specific gravity $10.0 \mathrm{~g} / \mathrm{cm}-3(+/-2.9 \mathrm{~g} / \mathrm{cm} 3)$

Diameter: $25 \mathrm{~mm}$

Axis: Obv. $\circlearrowright$ Rev. 乙

The Rhodes Museum has a particularly interesting silver tetradrachm (Fig. 2.1) from the reign of Ptolemy II who ruled from $283-c 260 \mathrm{BC}$ - reigning jointly with his father for the first two years and, in turn, being joined by his own son on the throne in about 260BC (Seltman 1933:241-242). The obverse side of the Ptolemy II coin held by Rhodes University shows a head, a clearly recognizable portrait of Ptolemy I, wearing a diadem with a faint suggestion of an aegis at the neck (very worn). The portrait is minted in quite high relief and the profile is obviously not idealized, showing a rather beaky nose (also seen on portraits of Cleopatra) and jutting chin, which must have been family traits. The reverse of the coin shows an eagle with a thunderbolt, the symbol of the Ptolemaic dynasty. The legend runs around the rim of the coin and reads (clockwise) ПTO EMAIOY/BA II E $2 \Sigma$ although the royal title is much worn. It was more usual for coins of this time to have legends running in two directions - downwards to the right and left of the picture or transversely from left to right, interrupted by the picture. The coins of the Ptolemies were amongst the first to show the legend in an uninterrupted arc or circle - an idea adopted later by Roman coinage (Regling 1969:44).

The coin is particularly interesting for three reasons. Firstly, after 270BC Ptolemy II minted quite a number of coins using unusual types, showing for example the conjoined profiles of his parents and that of his sister, Arsinoe, to whom he was married - hence his name, Philadelphus (Mackay 1971:69 - 71). The Rhodes specimen can thus be dated to fairly early in Ptolemy II's reign, between $283-270 \mathrm{BC}$, and is probably quite rare.

The second reason is that the silver tetradrachm of Egypt was fairly rare anyway- the reason being that silver metal in Egypt had a much higher value than it did in Greece. When the Ptolemies tried to institute the use of the silver tetradrachm on the Phoenician standard, the metal was worth more than the coin and was melted down. Within half a century the silver coins were mostly replaced by copper ones for internal circulation, silver coins being struck only for external trade. Once these silver tetradrachms were lost, however, new ones were struck from 
base metal, which were good enough for internal circulation but of no use outside the country (Milne 1931:113-114). Unfortunately, the provenance of the Rhodes coin is not known, but the weight per volume, or density of the coin in $\mathrm{g} / \mathrm{cm}-3,(10.0 \mathrm{~g} / \mathrm{cm}-3)$ suggests that it is in fact made of silver, not lead or some other base metal, thus making it even more rare and interesting.

The third point of note is the punchmark on the reverse of the coin - a floral design in a circle. There are a number of theories regarding these marks, which were common during the Hellenistic era. As Kraay (1976:15) points out, coins had an intrinsic value as a result of the precious metal from which they were made, and so long as they were accepted as official payment by the government that issued them, there was no reason to mark them further. However, when a new type was minted for whatever reason, the old coins would have to be revalidated, as it were, and it is suggested that this was done by using punchmarks - certainly quicker and cheaper than re-minting the whole coin.

Unlike coins from the rest of Alexander's successors, those from the Ptolemaic dynasty were based on the Phoenician standard (average weight of 14.4g; weight of the Rhodes coin, 14.02g), rather than the Attic. This may seem surprising, since the common use of the Attic standard for silver money, instituted by Alexander, became widespread, and meant that coins issued on this common standard could be used for trade in many areas. However, as Regling (1969:41-42) points out, coins from both areas (Attic and Phoenician) are not usually found together in hoards, which seems to indicate that they were used in two distinct economic trading areas.

\section{The Seleucid Empire}

The coins of the Seleucid dynasty are of a bewildering number of types, the Seleucid Empire being the largest belonging to any of Alexander's generals. However, the Seleucids began, as did all of Alexander's successors, by using the Alexander-type with their own name $\Sigma \mathrm{E} \Lambda \mathrm{EYKOY}$ and the royal title $\mathrm{BA} \Sigma \mathrm{I} \Lambda \mathrm{E} \Omega \Sigma$ on the reverse, although some of Seleucus I's Bactrian coins bore his portrait, rather than that of Heracles/Alexander (Seltman 1933:228). As Milne (1931: 113) points out, those rulers who were closer to the Greek world and traded with them were more hesitant in using portraits of living rulers on their coins since this would not "accord with Greek ideas of what was suitable and proper". However, the Seleucid Empire (particularly Bactria) was far from Greek trading areas and, as in Egypt, the use of living rulers' portraits on coins was probably more acceptable.

Seleucid coinage was very important to the commerce of the time. By the time of Seleucus IV, however, the empire was much smaller than that ruled by his father Antiochus III, since many of the former provinces - India, Bactria, Parthia and Pergamum were now established as independent (Mackay 1971:64; Sear 2002, vol. 2:650).

According to the museum catalogue, the Rhodes coin (Fig. 2.2) is a silver tetradrachm minted during the reign of Seleucus IV, called Philopator (187-175BC). Antiochus III had tried to promote himself as the champion of the autonomy of the Greek states and the Greek themes of the coin are consistent with the geo-political goals of the Seleucids, although by 187BC they had been defeated in war by Rome and were paying a heavy tribute. The obverse shows a portrait of Seleucus IV, but the portrait is similar to that of his father, Antiochus III ('the Great'), even to 
the lock of hair on the forehead and temple, sticking out from under the fillet (there are good reproductions of Antiochus III coins in Davis \& Kraay 1973).

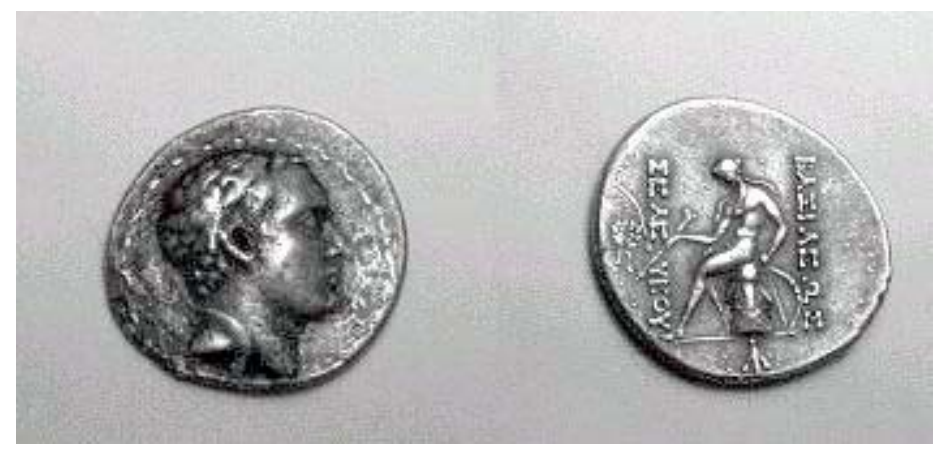

Fig. 2.2

Obverse: Profile head with diadem of Seleucus IV, r., with border;

Reverse: Naked Apollo seated on omphalos 1., holding arrow and leaning on bow; on 1., $\Sigma \mathrm{E} \Lambda \mathrm{EYKOY}$, on r. BA $\Sigma \mathrm{I} \Lambda \mathrm{E} \Omega \Sigma$; in field to 1., wreath and palm branch, ex. $\Delta \mathrm{I}$ monogram or anchor;

Weight: 16.3g;

Diameter: $29 \mathrm{~mm}$

Axis: Obv. 凹 Rev. 公

The reverse shows Apollo (from whom the Seleucids claimed descent) seated on the omphalos with a bow and arrow. This type was first used in this dynasty by Antiochus I who became king in $281 \mathrm{BC}$, but then it went out of fashion, being replaced by Heracles or Zeus. The Apollo-type was re-instated by Antiochus III (Seltman 1933:230) and appears on the Rhodes coin. Although the presence of Apollo is easily explained, no authors seem to comment on the presence of the omphalos - perhaps assuming that, since it was situated at Apollo's oracle at Delphi, it would be a logical place for him to sit. We, however, postulate two specific links to the Alexandrian empire.

Firstly, coins from the Babylonian mint of the Alexander-type were marked with $\mathrm{M}$ for Metropolis, indicating the importance of the city as Alexander's intended capital at the centre of his empire (Mackay 1971:60). Is it purely accidental that the Seleucids, also operating out of Babylon, should choose a symbol, the omphalos, associated with the centre of the world? Secondly, this very type was used by Philip, Alexander's father, when he was appointed as treasurer of the Amphictyonic Council in 339BC. Four years later, the council issued coins under their own name showing on the reverse Apollo, seated on the omphalos, his right elbow resting on his lyre (Seltman 1933:203).

Under the omphalos is what Seltman (1955:227) describes as an anchor, adopted as a Seleucid device because Seleucus I is purported to have had a birthmark in this shape on his thigh, but what Sear (2002, vol. 2:650, catalogue number 6966) describes as a monogram of $\Delta \mathrm{I}$. This device was used from the start of the dynasty, even when the Alexander-type was still prevalent 
(Mackay 1971:63). Although we have not found sources that mention the significance of the symbols, coins from the reign of Seleucus IV often show, in the field in front of the throne, a sheaf of wheat and what looks like a laurel wreath, presumably symbols of prosperity and success.

\section{BIBLIOGRAPHY}

Arrian Anabasis of Alexander. Brunt, P A Loeb Edition: Cambridge (Mass.) 1976.

Bellinger, A 1963. Essays on the coinage of Alexander the Great. New York: The American Numismatic Society.

British Museum Compass Collections Online 2005. Silver tetradrachm of Alexander the Great [Accessed 02/11/05] Available: www.thebritishmuseum.ac.uk/compass.

Carradice, I 1995. Greek Coins. The Trustees of the British Museum: British Museum Press.

Cartledge, P 2004. Alexander the Great: The hunt for a new past. Woodstock: The Overlook Press.

Davis, N \& Kraay, C M 1973. The Hellenistic Kingdoms. London: Thames \& Hudson.

Doty, R G 1982. Macmillan Encylopedic Dictionary of Numismatics. New York: Macmillan.

Goldsborough, R 2005. Lifetime versus Posthumous: Alexander the Great tetradrachms [Accessed 20/10/05] Available: http://rg.ancients.info/alexander/tets.html.

Hardy, R 1974. Royal propaganda of Seleucus I and Lysimachus. The Journal of Hellenic Studies 94:5065.

Head, B V 1887. Historia Nummorum: A manual of Greek Numismatics. Oxford: Clarendon Press.

Holt, F 2003. Alexander the Great and the Mystery of the Elephant Medallions. Berkeley: University of California Press.

Kontes, Z. S. The dating of coinage of Alexander the Great. Online publication of the Institute for Archeology and the Ancient World, Brown University [Accessed on 31/01/06]. Available: http://www.brown.edu/Departments/Old_World_Archaeology_and_Art/html/ epublications/papers/alexander_coinage/alexander.html.

Kraay, C M 1969. Greek Coins and History: Some current problems. London: Methuen.

Kraay, C M 1976. Archaic and Classical Greek Coins. London: Methuen.

Le Rider, G 2003. Alexandre Le Grand Monnaie, Finances et Politique. Paris: University of France Press.

Lexicon Iconographicum Mythologiae Classicae c1981 - 1997. Zurich: Artemis Publishers.

Mackay, J A 1971. Greek and Roman Coins. Arthur Barker Limited.

Milne, J G 1931. Greek Coinage. Oxford: Clarendon Press.

Parkin, M, Powell, M \& Matthews, K 2005. Economics (6e). London: Pearson.

Price, M 1974. Coins of the Macedonians. British Museum Publications.

Quennell, P \& Hodge, A 1979. History Today: Alexandrian Portraits 39:71.

Regling, K 1969. Ancient Numismatics: The coinage of Ancient Greece and Rome. Chicago: Argonaut Inc. Publishers.

Sear, D 2002. Greek Coins and their Values, Volumes 1 and 2. London: Seaby, an imprint of Spink and Son Ltd.

Seltman, C 1949. Masterpieces of Greek Coinage. Oxford: Bruno Cassirer.

Seltman, C 1955. Greek Coins: A history of metallic currency and coinage down to the fall of the Hellenistic Kingdoms. London: Methuen.

Wildwinds.com Online reference, attribution and valuation site for Ancient Greek, Roman and Byzantine coins [Accessed on 05/06/02] Available: www.wildwinds.com. 